Dr. S. Neumark had considerable experience before the Second World War as a lecturer and research worker in aerodynamics and applied mathematics in Warsaw, at the Technical University, the Aerodynamic Institute, and the Institute of Aeronautical Research. During 1937-39 he was professor of mechanics in the Polish Air Force College, Warsaw, and while in the Polish Air Force he joined the Royal Aircraft Establishment, Ministry of Supply, remaining there on demobilization. He has done distinguished work in theoretical aerodynamics, especially investigations into problems of stability and control and in fluid motion, including theoretical flow over sweptback wings, and he is widely known for his researches in these fields.

Dr. W. G. S. Parker entered the Royal Aircraft Establishment, Ministry of Supply, in 1936. He worked initially on a wide variety of physicochemical problems in the aircraft field and made many valuable contributions. Since 1946 he has been concerned with the difficult problems of the mechanism of burning and decomposition of oxidizing fuels and propellants, and his work in this sphere has earned him an international reputation. In particular his research on carbon formation and on the structure of diffusion flames has advanced considerably the understanding of combustion in air flames and has had important applications in the study of fire prevention.

DR. S. M. PARTRIdGe, for two years prior to joining the D.S.I.R., held a Beit Memorial Fellowship for Medical Research, working at the Lister Institute for Preventive Medicine. He joined the D.S.I.R. in 1942 to assist a team at the Low Temperature Research Station, Cambridge, studying dehydrated meat, and was responsible for the development on the pilot-plant scale of a process for its manufacture. Since the Second World War, in the course of his investigations on connective tissues (cartilage, elastic tissues, etc.), he has made notable contributions to analytical methods in biochemistry. He was a pioneer in the application of partition chromatography on filter paper to the analysis of sugars and in the development of displacement chromatography of organic compounds using ion-exchange resins. His contributions to biochemistry are finding numerous applications, not only to foods but also to medical research and other fields of applied biochemistry.

Mr. E. O. Powell was with the Chemical Defence Experimental Establishment, Ministry of Supply, during 1941-46, and after a short period on industrial research re-joined the Ministry of Supply in the Microbiological Research Department in 1947. His versatility and insight have enabled him to make valuable contributions in such diverse fields as bacteriology, chemistry, mathematics and physics. $\mathrm{He}$ has done particularly important work in the development of micro-manipulative techniques for the study of individual bacterial cells, and also in bacterial genetics.

Mr. G. D. Robinson joined the Meteorological Office in 1936. He has made valuable detailed studies in atmospheric radiation and in the transfer of heat, momentum and water vapour between the ground and the air, and his published papers on this work are widely recognized as important contributions. These investigations of basic problems of energy exchange in the atmosphere are to be extended.

\section{WORLD FEDERATION OF SCIENTIFIC WORKERS}

\section{ASSEMBLY AT BUDAPEST}

$T$ HE World Federation of Scientific Workers held its third assembly during September $12-14$ in Budapest, at the invitation of the Hungarian Association of Scientists and Engineers. Thirty-five representatives of organizations of scientists in Bulgaria, Canada, China, Czechoslovakia, Denmark, France, Great Britain, Hungary, India, Poland and the U.S.S.R. attended the sessions. The proceedings were opened by the president, Prof. Frederic JoliotCurie. The president's speech emphasized the need for scientists to inform the public of the useful things which science can provide, and to try to promote international exchanges of scientific literature and of personal visits as a contribution to improving international relations. Apart from organizational matters, the Assembly discussed certain questions of general interest to scientists. Reports on the salaries and conditions of work of scientists in various countries represented at the Assembly were presented. Special attention was devoted to the difficulties which are at present being experienced in connexion with exchanges of scientific books and periodicals. It is greatly to be hoped that an improvement in these exchanges can be achieved by the concerted action of all scientists in all countries. It was also decided to extend the publications of the Federation with the view of giving a presentation of the positive and constructive way in which science could contribute to the welfare of all peoples if it were freed from many of its present restrictions.

'The resolutions passed by the Assembly made the following points: $(a)$ that scientific workers everywhere should strive to secure the peaceful solutions of all international differences, so that less attention will be given to military preparations and more to the peaceful uses of science; $(b)$ that governments could and should, by international negotiations, reach agreement regarding the prohibition of weapons of mass destruction; and (c) that academic freedom should be preserved and that the restrictions to which scientists are subjected should be reduced.

Laboratories and museums of all kinds were visited by delegates to the Assembly, and Hungarian scientists showed great pleasure in discussing scientific matters with their guests. To judge from the laboratories which have been recently completed and from those which are now in the process of building, it may be said that scientific institutions are rapidly developing and that large funds are available for this purpose. Many university teachers and research workers are engaged in writing text-books in the Hungarian language. The number of students in universities and institutes of higher education has increased seventeen-fold since 1939. During the same period the number of technical universities has increased from one to five, and the number of scientific books published each year by a factor of ten. Parallel with this great internal growth in education and research, there has developed a need for better contact with foreign science.

A novel feature of this Assembly was the holding of lectures on scientific subjects, given to the various Hungarian scientific societies, and they evoked great interest and discussion. Among the lecturers were: Prof. E. Aubel (France), on the mechanism and role of the biological reduction of nitrates; Prof. J. D. 
Bernal (Great Britain), on (1) X-ray analysis of materials, and (2) the structure of proteins; Prof. $K$. Bratanov (Bulgaria), on the application of vegetative and sexual hybridization in stock-breeding; Dr. M. Degerbøl (Denmark), on prehistory and zoology ; Prof. E. Grillot (France), on luminescence of crystalline minerals ; Acad. L. Infeld (Poland), on the influence of Copernicus on the development of physics; Prof. Y. Le Grand (France), on recent researches on optical physiology; Acad. V. P. Nikitin (U.S.S.R.), on electrical welding; Sir Robert Watson-Watt (Great Britain), on the education of scientific workers; Dr. W. A. Wooster (Great Britain), on diffuse $\mathbf{X}$-ray reflexions and the physical properties of crystals.

Excursions were arranged for the delegates to various centres of interest, in particular to the new steel town of Stalinvaros, to the ancient royal seat of Vesperen, to the district surrounding Lake Balaton and to a collective farm. Receptions were given by the Hungarian Academy of Sciences and by various delegations. Visits to the opera and ballet were also arranged. Just before the last session of the Assembly, a concert was given by the following distinguished musicians: Annie Fischer, Alexander Svéd, Ede Zathureczky, Mihaly Szèkely and Maria Gyurkovits. The hospitality extended to the guests was truly magnificent and they will long remember their stay on the island Margitszigit in the Danube.

Prof. F. Joliot-Curie (France) was re-elected president. Other officers re-elected included Prof. J. D. Bernal, Prof. C. F. Powell (vice-presidents), Dr. W. A. Wooster (treasurer), and Dr. E. G. Edwards (honorary secretary). The total membership of the scientific and technical organizations affiliated to the Federation has risen from 44,000 in 1951 to 136,770 in 1953, and it is distributed over thirteen countries. W. A. Wooster

\section{SYMPOSIUM ON GEOCHEMISTRY AT ZURICH}

A

SYMPOSIUM Pon geochemistry was held in Zurich during August 11-13 under the auspices of the International Union of Chemistry. It was presided over by Dr. M. Fleischer and by the local chairman, Prof. C. Burri, with Prof. T. F. W. Barth acting as secretary. More than sixty members, representing eighteen countries, were present. This meeting was the first international gathering of geochemists.

The material read at the symposium was divided into two groups : (1) reports relating to the problem of organizing, completing and making available geochemical data; (2) papers on geochemistry and allied subjects. The first group of communications included the following reports: by M. Fleischer on the geochemical work of the Geochemistry and Petrology Branch of the U.S. Geological Survey and on the progress of the revision of Clarke's "Data of Geochemistry" (Bull. 770, U.S. Geol. Surv.); by Marjorie Hooker on the progress made in the revision of Washington's "Chemical Analyses of Igneous Rocks" (Prof. Pap. 99, U.S. Geol. Surv.) ; by W. Müller on the geochemical work of Gmelin Institute; by P. Rosbaud on the publication of geochemical papers in Geochimica and Cosmochimica Acta (Pergamon Press, London); by K. Rankama on the compilation, revision and organization of current geochemical work; and by 'T. F. W. Barth on current geochemical research throughout the world. The second group comprised some twenty-five papers dealing with a variety of subjects, such as the geochemistry of certain elements, the distribution and abundance of elements in ground water, sea water, sedimentary and igneous rocks, the association of uranium with mineral hydrocarbons, the uranium content of deep-sea sediments, the geochemistry of petroleum and allied substances, the minerals of pegmatites, the composition and origin of meteorites, petrochemistry and petrogenesis, and the use of the periodic system of geochemistry. A fuller report of this meeting will be published in Geochimica and Cosmochimica Acta.

The meeting took place in the Mineralogical and Petrographical Institute of the Federal Technical College in Zurich by invitation of Prof. C. Burri and with the assistance of the staff of the Institute. After the meeting, a group of members of the symposium took part in an excursion to the Eastern Gotthard Massif (August 14-15), led by Prof. C. Burri.

During the symposium six members of the Com. mission on Geochemical Localization of the Elements of the International Union of Chemistry, who were present, met and, among other business, elected Prof. H. C. Urey as a member of the Commission in succession to the late Prof. P. Niggli, and Prof. C. Burri as an observer attached to the Commission. The composition of the Commission (subject to confirmation by the Committee of the International Union of Chemistry) is as follows: M. Fleischer (Washington), president; T. F. W. Barth (Oslo), vice-president; K. Rankama (Helsinki), secretary: and members, H. S. Brown (Pasadena), C. W' Correns (Göttingen), D. Guimaraes (Belo Horizonte) A. Holmes (Edinburgh), E. Raguin (Paris), S. I. Tomkeieff (Newcastle upon Tyne) and H. C. Urey (Chicago).

\section{EFFECTS OF ATMOSPHERIC POLLUTION ON VEGETATION}

$\mathrm{O}$ September 9, the last day of the Liverpool meeting, Sections K (Botany) and K* (Forestry) of the British Association jointly discussed the increasingly important topic of the deleterious effects of chemical substances in the atmosphere on plant growth. It is all too well known that soot and gaseous products of combustion, such as sulphur dioxide, when released into the air over and around large cities and industrial areas, not only cause damage to buildings but also impair the health of animals and human beings. The damage to vegetation due to the same causes is less widely known but is very familiar to those who have to cultivate plants in forest, field, gar. den or glasshouse where atmospheric pollution occurs. In Great Britain the damage to glasshouse plants was especially noticeable during the unusually severe fogs that occurred during the winter of 1952-53. That the problem is not confined to Great Britain is shown by catastrophes such as those which occurred in the Meuse valley in Belgium in 1930, at Donora in Pennsylvania in 1948 and at Poza Rica in Mexico in 1950 , in all of which localities much human illness and numerous deaths were shown to be due directly to short periods during which the atmosphere was more highly polluted than usual. A large-scale investigation of the damage to vegetation caused by 